\title{
Emma Talbot
}

\section{Out of Sight, Out of Mind: New Zealand's Latest Attempt at Prostitution Reform}

Submitted for the LLB (Honours) Degree

Faculty of Law

Victoria University of Wellington

2014 


\section{Table of Contents}

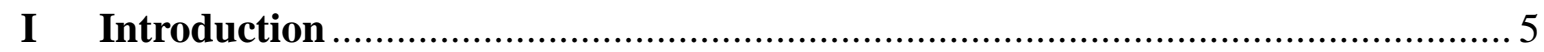

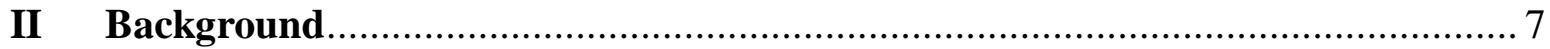

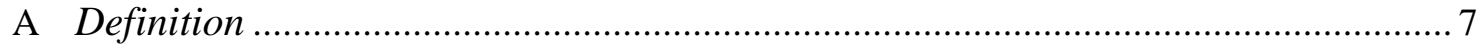

B Prostitution in New Zealand prior to the passage of the Prostitution Reform Act 2003

C Prostitution Reform Act 2003 and the modern landscape of street-based

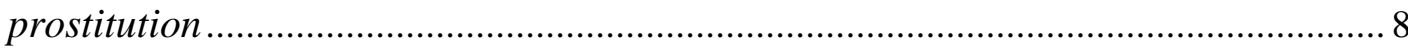

D The harms resulting from street-based prostitution .................................................... 10

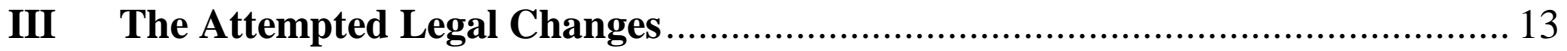

A The Manukau City Council (Regulation of Prostitution in Specified Places) Bill and The Manukau City Council (Control of Street Prostitution) Bill .............................. 13

B The Prostitution Reform (Control of Street-based Prostitutes and Their Clients)

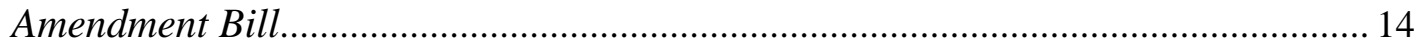

IV The Likely Efficacy of these Proposed Legislative Changes ............................ 15

A Legislation in this form is an inappropriate solution to the harms of street-based

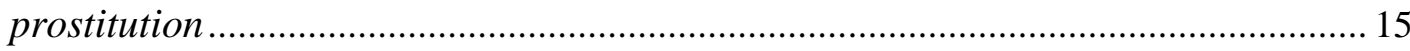

B Criminalisation, in general, is inappropriate for these issues ................................ 22

V Alternative Measures for Addressing Issues around Street-based Prostitution . 25

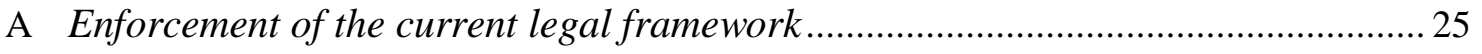

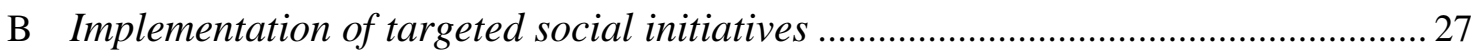

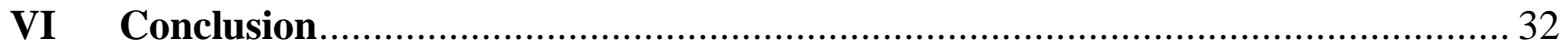




\begin{abstract}
The Prostitution Reform Act 2003 decriminalised all aspects of commercial sex work. It was believed this would reduce the presence of prostitutes on the streets and the associated harms, in particular neighbourhood nuisance, increased violence and greater presence of underage persons engaging in prostitution. However, street-based prostitution and harm reduction has not occurred. This has prompted attempts to confine the parameters of the decriminalised prostitution regime: The Manukau City Council (Control of Street Prostitution) Bill, which was ultimately unsuccessful and led to The Manukau City Council (Regulation of Prostitution in Specified Places) Bill, and the recent Prostitution Reform (Control of Street-based Prostitutes and Their Clients) Amendment Bill. This paper considers how these attempts have proposed to achieve amelioration of the harms around street-based prostitution. This paper argues legislation will only further frustrate the issues because criminalisation, both in the manner proposed by these attempts, and more generally, is inappropriate for addressing issues of streetbased prostitution. This paper recommends targeted social initiatives should be implemented as the best model for addressing the harms of street-based prostitution.
\end{abstract}

\title{
Keywords
}

Prostitution law reform, street-based prostitution, social support initiatives, decriminalisation. 
Emma Talbot, "Out of Sight, Out of Mind" New Zealand's Latest Attempt at Prostitution Reform”

For Bluebell 


\section{Introduction}

In 2003 New Zealand became the first country in the world to decriminalise all aspects of prostitution through passing the Prostitution Reform Act (PRA). Despite this, prostitution remains a contentious issue. A matter of particular debate is whether street-based prostitution should remain decriminalised; in other words, whether prostitution-related activities should be confined indoors, to brothels, small owner-operated business (SOOBs) or private premises. The mounting concern around neighbourhood nuisance, violence, the growing visibility of morally offensive behaviour and of underage persons on the street, has prompted calls for further reform. For the purpose of this essay these issues will be termed "the harms of streetbased prostitution."

This paper will consider the resulting proposed legislative attempts to remove prostitution from the streets, the Manukau City Council (Control of Street Prostitution) Bill (the CSP Bill), which was unsuccessful and led to the re-drafted Manukau City Council (Regulation of Prostitution in Specified Places) Bill (the RSP Bill), and the Prostitution Reform (Control of Street Prostitutes and their Clients) Amendment Bill (the PRAB). ${ }^{1}$ These Bills purport that recriminalisation of street-based prostitution will alleviate its associated harms.

This paper will discuss the harms of street-based prostitution briefly, and, accepting prima facie they are of notable concern, will consider how efficacious a legislative approach in the current form of the stated Bills will be in working to remedy the issues. ${ }^{2}$

This paper will argue that a legislative approach will only frustrate the harms of street-based prostitution. For example, prostitution-related activities are likely to be driven underground leading to exacerbated violence and risk, the support given by community agencies and police

\footnotetext{
${ }^{1}$ The PRAB is currently in the ballot box. This paper recognises it may never be heard by Parliament and even if it were, may not succeed at first reading. However, this paper recognises the extent of public support in favour of this Bill and thus will consider it in its current form.

${ }^{2}$ Such a topic is potentially far-reaching. This paper is primarily concerned with the issue of street prostitution of women and young girls. It is recognised issues such as male and transgender prostitution and also international human trafficking would be affected by the legal changes the three Bills propose. However, in so far as issues relating to these groups differ from those of street-based prostitution and of underage prostitution, they are outside the scope of this paper.
} 
to street-based prostitutes will be undermined, and a group of already vulnerable people will be further marginalised.

This paper will then propose that in general criminalisation is an inappropriate response to the issues resulting from street-based prostitution. ${ }^{3}$ Experiences from comparative jurisdictions and issues around the effect of deterrence will be discussed.

However, this paper does not purport to suggest that prostitution is not harmful and demeaning. The author agrees with Farley's thesis that whatever its legal status, prostitution causes significant harm to women, both physically and emotionally. ${ }^{4}$ Nonetheless, the most effective and appropriate way to address the harms of street-based prostitution is through targeted social initiatives, which are most successful within a decriminalised regime. This paper will consider initiatives such as safe-house brothels, transitional housing and women's drop in centres, and increased public education as possible solutions for the New Zealand context. Social initiatives are most effective because they work to address the deeper issues behind engagement in prostitution. A balance must be struck between the need to protect and support those engaging in prostitution and the need to ensure local communities are respected, in terms of maintaining a clean, safe and morally sound environment. Enforcement of the current legal framework coupled with such social initiatives will best achieve this balance and thus work to remedy the issues that the proponents of the CSP Bill, RSP Bill and the PRAB claim require a legislative response.

\footnotetext{
${ }^{3}$ The author has recently been confronted with arguments that decriminalised or legalized prostitution regimes are conducive to forced sex trafficking and slavery, and further, may undermine efforts to prevent this crime. This has challenged many of the arguments underpinning this paper. However, delving further into this issue is outside the scope of this paper (and the time constraints). Therefore, the author would like to emphasis the arguments in this paper are based specifically on the current New Zealand legal framework and the changes these particular pieces of proposed legislation hope to create, for example criminalizing only one aspect of prostitution, while allowing indoor-aspects of prostitution to remain decriminalised. The arguments this paper presents, therefore, are a pragmatic response for the New Zealand context.

${ }^{4}$ Melissa Farley "Bad for the Body, Bad for the Heart: Prostitution Harms Women Even if Legalized or Decriminalized" (2004) 10 VAW 1087 at 1094.
} 


\section{Background}

\section{A Definition}

The PRA defines prostitution loosely as "the provision of commercial sexual services." ${ }^{5}$ For the purpose of this paper street-based prostitution will be defined as the exchange of sexual services in a broad sense, and not limited to actual intercourse for consideration occurring outside an enclosed private premise. Enclosed private premise is defined as private dwellinghouses, maraes, and other places not frequently accessed by the public, for example hospitals or shops. ${ }^{6}$ Places where a third party may view the transaction are also excluded. ${ }^{7}$

\section{B Prostitution in New Zealand prior to the passage of the Prostitution Reform Act 2003}

Prostitution is a prevalent norm in urban life. ${ }^{8}$ In New Zealand before the PRA essentially all prostitution related activities were illegal. For example, Section 147 of the Crimes Act 1961 prohibited brothel-keeping, s 148 prohibited living on the earnings of prostitution, and s 149 prohibited procuring sexual intercourse. Under s 26 of the Summary Offences Act 1981 soliciting was illegal. However, these extensive legal provisions did not prevent prostitution. A Christchurch School of Medicine Study (the CSOM) estimated that before 2003 there were 5932 prostitutes across New Zealand's five main centres, of which 637 were street-based. ${ }^{9}$

The pre-PRA law created an environment fraught with double standards (clients were "outside the reach of the law") and exploitation. ${ }^{10}$ Massage parlours provided a covert front for prostitution, meaning prostitutes were at the mercy of parlour operators to ensure they remained

\footnotetext{
${ }^{5}$ Prostitution Reform Act 2003, s 4(1).

${ }^{6}$ Prostitution Reform (Control of Street Prostitution and Their Clients) Amendment Bill 2014, cl 5, and see cross reference to Search and Surveillance Act 2005, s 3.

${ }^{7}$ Prostitution Reform (Control of Street Prostitution and Their Clients) Amendment Bill 2014, cl 5 (b).

${ }^{8}$ Phil Hubbard "Red-light districts and Toleration Zones: geographies of female street prostitution in England and Wales" (1997) 29 Area 129 at 129.
}

${ }^{9}$ Report of the Prostitution Law Review Committee on the Operation of the Prostitution Reform Act 2003 (Ministry of Justice, May 2008) at 25.

${ }^{10}$ At 20 . 
hidden from authority. ${ }^{11}$ This meant hefty fines could be demanded for absence or lateness and refusal to undertake a transaction with a particular client was not possible. ${ }^{12}$ Moreover, there were severe sanctions for prostitution-related convictions, including prevention of further employment in a massage parlour for 10 years. ${ }^{13}$ This rendered street-based prostitution the only option for some. The streets were a particularly dangerous environment where physical violence, assault, rape and murder were common. ${ }^{14}$ Accordingly, prostitutes were forced to conduct transactions "in the darkest corners," hidden from police view, and were reliant on illegal associations for protection, for example physical protection by pimps. ${ }^{15}$ Moreover, the police's ability to protect prostitutes from violence was hindered because their primary focus was preventing prostitution itself. ${ }^{16}$ This meant prostitutes were reluctant to report incidents or concerns to police for fear they too would be arrested. ${ }^{17}$ It was frustration with this environment that prompted calls for reform.

\section{Prostitution Reform Act 2003 and the modern landscape of street-based prostitution}

The PRA decriminalised all aspects of prostitution. It aimed to create a legal framework that would safeguard the human rights of prostitutes, protect them from exploitation, promote occupational health and safety within the sex industry, and, prohibit prostitution of persons under $18 .{ }^{18}$ This has been achieved to some extent. The PRA requires brothel operators, SOOBS, and individual sex workers and clients to adopt and promote safer sex practices. ${ }^{19}$ For example, the prostitute must be provided with appropriate contraceptives and her right to refuse a client must be recognised. Further, brothel operators must hold a valid operating certificate

\footnotetext{
${ }^{11}$ Report of the Prostitution Law Review Committee, above n 9, at 20.

12 At 29.

${ }^{13}$ Gillian Abel, Lisa Fitzgerald, Catherine Healy and Aline Taylor (eds) Taking the crime out of sex work: New Zealand sex workers' fight for decriminalisation (The Policy Press, Bristol, 2010) at 37.

14 At 40-41.

${ }^{15}$ Lynzi Armstrong "Managing risks of violence in decriminalised street-based sex work: a feminist (sex worker rights) perspective" (BA ( $\mathrm{PhD})$ Thesis Victoria University of Wellington, 2011) at 111; Christine Harcourt, Sandra Egger and Basil Donovan "Sex work and the law" (2005) 2 Sexual Health 121 at 126.

${ }^{16}$ Abel, Fitzgerald, Healy and Taylor, above n 13, at 40.

17 At 40

${ }^{18}$ Prostitution Reform Act 2003, ss 3 and 9.

${ }^{19}$ Prostitution Reform Act 2003, s 9.
} 
and are prohibited from employing any person under the age of $18 .{ }^{20}$ Health Officers may inspect premises to ensure compliance with such health and safety requirements. ${ }^{21}$

However, health and safety requirements in the PRA are primarily targeted at indoor prostitution and the street remains relatively un-regulated. For example, provision of health and safety information and services are left to voluntary efforts by NZPC and community services such as The Salvation Army and Streetreach, and detection of underage prostitutes is left to police, Maori Wardens and the aforementioned community organisations. This is perhaps explained by the belief that decriminalisation would significantly reduce the numbers of street-based prostitutes. ${ }^{22}$ Whether this has in fact occurred is ambiguous.

On one hand, the CSOM study suggests the number of persons engaged in street-based prostitution has decreased following reform, from an estimated 652 to an estimated 253 streetbased prostitutes across New Zealand. ${ }^{23}$ Yet, on the other hand, the percentage of the total number engaged in prostitution on the streets as their preferred platform has remained relatively similar, from 10.7 before reform, to 11 percent in $2007 .{ }^{24}$ Contrary to the CSOM estimate, Streetreach and the Salvation Army claim there has been a visible increase of street-based prostitutes since reform. ${ }^{25}$

Such estimates need to be considered carefully. Exact numbers are difficult to estimate as, despite decriminalisation, prostitution, and especially street-based prostitution remains a stigmatized and discreet affair. ${ }^{26}$ Moreover, even with increased visibility of street workers, police no longer maintain registers of known prostitutes. ${ }^{27}$ For the individual worker, activity

\footnotetext{
${ }^{20}$ Report of the Prostitution Law Review Committee, above $\mathrm{n} 9$, at 23.

${ }^{21}$ At 23-29.

${ }^{22}$ At 32-3.

${ }^{23}$ At 118.

${ }^{24}$ At 118.

${ }^{25}$ At 118-119.

${ }^{26}$ At 29.

${ }^{27}$ At 32.
} 
on the street may be irregular, for example, an occasional night's work to supplement a day job or benefit. ${ }^{28}$

\section{$D$ The harms resulting from street-based prostitution}

However, regardless of an arguable increase or decrease in numbers, the presence of streetbased prostitution in local communities has adversely affected residents. The issues around Hunters Corner and Northcrest car park, Papatoetoe best exemplify the extent of neighbourhood nuisance caused by street-based prostitutes. There are many complaints of street-based prostitutes discarding offensive and dangerous litter in public places, used condoms, syringes and glass bottles are examples. ${ }^{29}$ Local business owners have also complained of street-based prostitutes vandalising their businesses, including using business exteriors as toilet facilities. ${ }^{30}$

Traffic noise has also been highlighted as a problem arising from the presence of street-based prostitutes. Both Hunters Corner and Northcrest are situated as to allow traffic to circulate around side streets via interconnecting car-parks. ${ }^{31}$ These are popular routes for prospective clients and are causing increasing late night road noises. ${ }^{32}$

Residents have also complained about anti-social behaviour, particularly, rowdy, offensive, and intimidating behaviour, fights, threats and turf wars. ${ }^{33}$ This has created an environment of fear. ${ }^{34}$ For example, residents have reported a reluctance to notify police of instances of violence and unlawful behaviour for fear the street-based prostitute would identify the

\footnotetext{
${ }^{28}$ Report of the Prostitution Law Review Committee, above n 9, at 118.

${ }^{29}$ Review of Street-based Prostitution in Manakau City (Ministry of Justice, April 2009) 5-6.

${ }^{30}$ Auckland City Council "The street prostitution industry in the southern communities of Auckland: the need for legislative control to reflect the intent of the Prostitution Reform Act" (May 2012) <www.aucklandcouncil.govt.nz> at 8 .

${ }^{31}$ Review of Street-based Prostitution in Manakau City, above n 29, 5-6.

32 At 5-6.

${ }^{33}$ Auckland City Council "The street prostitution industry in the southern communities of Auckland: the need for legislative control to reflect the intent of the Prostitution Reform Act” (May 2012) <www.aucklandcouncil.govt.nz> at 10-11.

${ }^{34}$ At $10-11$.
} 
complainants. ${ }^{35}$ Such issues are angering local residents and causing them to relocate local businesses to other areas. ${ }^{36}$

Street-based prostitution also poses safety risk to prostitutes themselves. Plumridge and Abel found violence towards street-based prostitutes is more prevalent than violence towards indoor workers. ${ }^{37}$ For example, over a period of 12 months, 13.4 percent of street-based prostitutes were physically assaulted by a client and 39.4 percent were threatened with violence either by a client, other prostitute, or member of the public. ${ }^{38}$ This is comparable to 10.4 percent of managed indoor workers who experienced physical assault and 9.3 percent of managed indoor workers who experienced threats of abuse. ${ }^{39}$ It is suggested that this disparity is because streetbased prostitutes face a broader range of violence-related risks, including assault, spiking of drinks, robberies and sexual assaults. ${ }^{40}$

Illegal drug use is another concern. CSOM asked street-based prostitutes whether they would accept drugs instead of money. ${ }^{41}$ In Auckland, 71.8 percent responded in the affirmative, in Wellington, 45.3 percent, and in Christchurch, 37 percent. $^{42}$

Residents are also concerned about public occurrences of immoral or offensive behaviour. There have been reports that sex work regularly occurs in public, during the day and with disregard to the presence of local shoppers and children, for example in view of school buses. ${ }^{43}$

\footnotetext{
${ }^{35}$ Auckland City Council "The street prostitution industry in the southern communities of Auckland: the need for legislative control to reflect the intent of the Prostitution Reform Act" (May 2012)

<www.aucklandcouncil.govt.nz> at 10-11.

36 At 10-11.

${ }^{37}$ Armstrong, above n 15, at 34.

38 At 34.

39 At 34.

${ }^{40}$ Anna Loren "A waste of time Prostitution law change" Manukau Courier (online ed, Auckland, 30 December 2012).

${ }^{41}$ Report of the Prostitution Law Review Committee above n 9, at 123.

42 At 123 .

${ }^{43}$ Auckland City Council "The street prostitution industry in the southern communities of Auckland: the need for legislative control to reflect the intent of the Prostitution Reform Act" above n 11, at 7.
} 
The final harm to be discussed is the belief that street-based prostitution is the gateway for underage prostitution. Despite provisions prohibiting commercial sex transactions with an underage person, underage prostitution is a significant issue. CSOM found 56 percent of streetbased prostitutes entered the industry while underage. ${ }^{44}$ Furthermore, underage persons make up 1.3 percent of the total sex industry. ${ }^{45}$ In 2013, this was brought to the fore with claims girls as young as 12 and 13 were earning $\$ 600$ per night on the streets of Otara. ${ }^{46}$

Again, these estimates need to be considered carefully. Actual figures may be difficult to discern as those reported to be underage prostitutes may, in fact, be "hangers-on" of prostitutes on the periphery of sex work. ${ }^{47}$ Further, many suspected underage prostitutes are merely bored youth, loitering around shopping malls and parks consuming alcohol. ${ }^{48}$

Public dissatisfaction with the failure of the PRA to address harms around street-based prostitution and the effect this is having in the local community has prompted calls for further legislative reform. ${ }^{49}$ It is believed legislation will be effective in reducing street-based prostitution by means of deterrence and criminal sanction, thus alleviating the associated harms. Such a belief is consistent with the argument that law and policy makers formulate and apply criminal law on the conviction that it is effective in influencing conduct. ${ }^{50}$

\footnotetext{
${ }^{44}$ Report of the Prostitution Law Review Committee above n 9, at 103.

45 At 16.

${ }^{46}$ Abby Gillies "Underage prostitutes earning \$600 per night” Otago Daily Times (online ed, Dunedin, 27 March 2013); Duncan Garner "Girls as young as 12 working as prostitutes in South Auckland" (Podcast, 27 March 2013) Radio Live <www.radiolive.co.nz〉.

${ }^{47}$ Duncan Garner "Girls as young as 12 working as prostitutes in South Auckland" (Podcast, 27 March 2013) Radio Live <www.radiolive.co.nz>.

${ }^{48}$ Duncan Garner "Girls as young as 12 working as prostitutes in South Auckland" (Podcast, 27 March 2013) Radio Live <www.radiolive.co.nz>.

${ }^{49}$ Prostitution Reform (Control of Street Prostitution and Their Clients) Amendment Bill 2014, general policy statement.

${ }^{50}$ Paul H Robinson and John M Darley “Does Criminal Law Deter? A Behavioural Science Investigation” (2004) 24 OJLS 173 at 173.
} 


\section{The Attempted Legal Changes}

\section{A The Manukau City Council (Regulation of Prostitution in Specified Places) Bill and The Manukau City Council (Control of Street Prostitution) Bill}

The RSP Bill is a local Bill purporting to limit by way of re-criminalisation street-based prostitution in the former Manukau city. The council will be granted power to make bylaws designating certain areas as "specified places" under the legislation. Street-based prostitution will be rendered criminal and prohibited from occurring in these "specified places." ${ }^{51}$ This power is limited. The council will not have authority to regulate the location of brothels or SOOBs and will not have authority to prohibit street-based prostitution in all public areas. ${ }^{52}$ Further, before designating an area as a "specified place", the council must be satisfied prostitution is causing, or likely to cause, a nuisance or serious offence to members of that local area, or, will be incompatible with the existing character and use of that area. ${ }^{53}$

This Bill followed the unsuccessful CSP Bill which purported to re-criminalise street-based prostitution across all Manukau city. The Local Government and Environment Select Committee argued the primary reason for not supporting the CSP Bill was because it criminalised a segment of society based on geographical location. ${ }^{54}$ While the Select Committee accepted local legislation as a legitimate instrument in New Zealand, it argued it is inappropriate for criminal issues as it would cause inconsistency and thus uncertainty based on geographical area. ${ }^{55}$ This would pose jurisdictional and enforcement issues. ${ }^{56}$ Further, although it was argued that the issues around street-based prostitution were particular to Papatoetoe and thus justified the creation of localized criminal offences, the Select Committee stated that as New Zealand is not divided into federal states, there is no established legal framework to

\footnotetext{
${ }^{51}$ Manakau City Council (Regulation of Prostitution in Specified Places) Bill 2010 (197-1), cl 12.

${ }^{52}$ At cl 5(4).

${ }^{53}$ At cl 5(4).

${ }^{54}$ Manukau City Council (Control of Street Prostitution) Bill 2005 (6-1) (select committee report) at 2.

${ }^{55}$ At 2.

${ }^{56}$ At 2.
} 
manage enforcement of different criminal offences on a regional basis. ${ }^{57}$ The RSP Bill is an attempt by the drafters to improve the approach to the same issue.

At the time of writing, the RSP Bill is awaiting Select Committee report; therefore, only initial comments can be made. However, persuasive arguments were made during the Bill's first reading suggesting this approach poses the same jurisdictional errors as the CSP Bill. ${ }^{58}$ Identifying one area as a specified place will merely cause street-based prostitutes, and the associated harms, to displace to a non-specified place. ${ }^{59}$ When this new place becomes a problem area, the council will have no alternative but to render this area also a specified place. Such process will repeat, until essentially the entire city is a specified place in which streetbased prostitution is prohibited. This will create the same jurisdictional problems as proposed by the CSP Bill.

\section{B The Prostitution Reform (Control of Street-based Prostitutes and Their Clients) Amendment Bill}

The PRAB therefore attempts to address the jurisdictional concerns the CSP Bill and RSP Bill have raised by seeking to re-criminalise street-based prostitution across New Zealand. Proponents of the PRAB also recognise street-based prostitution harms are not confined to Papatoetoe, but are also prevalent in wider Auckland, Christchurch, Wellington and some smaller cities such as Tauranga and Nelson. Accordingly, if successful, this Bill will amend s 7 of the PRA by inserting the following:

Section 7A Commercial sexual services prohibited if not in brothels, small owner-operated brothels or enclosed private premises

(1) A client may purchase and a sex worker may sell commercial sexual services only inside a brothel, a small owner-operated brothel, or enclosed private premises.

\footnotetext{
${ }^{57}$ Manukau City Council (Control of Street Prostitution) Bill 2005 (6-1) (select committee report) at 2.

58 (8 September 2010) 666 NZPD 13792.

${ }^{59}$ (8 September 2010) 666 NZPD 13792.
} 
(2) A client and a sex worker may engage in commercial sexual services only inside a brothel, small owner-operated brothel, or enclosed private premises.

(3) A sex worker may not solicit on a street or other public place for the provision of commercial sexual services.

(4) A client may not seek commercial sexual services from a sex worker soliciting on the street or other public place.

(5) A client or sex worker who contravenes any of subsections (1) to (4) without reasonable excuse, commits an offence and is liable on conviction to a fine not exceeding $\$ 2000 .^{60}$

This provision hopes to eradicate prostitution from the street. However, the following section of this essay will argue this will not be achieved. Legislation, and thus the provisions proposed by the RSP Bill or the PRAB, will not work to stop street-based prostitution or its associated harms. In fact, this essay will even argue that legislation would work to exacerbate the harms.

\section{The Likely Efficacy of these Proposed Legislative Changes}

A Legislation in this form is an inappropriate solution to the harms of street-based prostitution

(a) Re-criminalisation will cause issues of displacement

It is argued that a legislative attempt, as proposed by the RSP Bill and the PRAB, will only frustrate the harms of street-based prostitution. First, the RSP Bill's proposal to limit places in which street-based prostitution may occur may be as problematic as entire prohibition as it will merely cause displacement of street-based prostitutes to other areas. This reflects a "not-in-mybackyard" approach to the harms of street-based prostitution which can only ever be a temporary solution. ${ }^{61}$ In the United Kingdom, for example, greater police presence and "arrest

\footnotetext{
${ }^{60}$ Prostitution Reform (Control of Street Prostitution and Their Clients) Amendment Bill 2014, cl 6.

${ }^{61}$ Teela Sanders, Paying for pleasure: Men who buy sex (Willan Publishing, Devon, 2008) at 138-139 and 147.
} 
spats" caused street-based prostitutes simply to move to nearby areas. ${ }^{62}$ Sanders theorised displacement into three categories. First, temporal displacement, where clients merely sought prostitutes at alternative times. ${ }^{63}$ Second, tactical displacement, where clients sought prostitutes by alternative means, for example, via mobile phones or internet communication. ${ }^{64}$ Third, spatial displacement, where prostitutes and clients relocated geographically. ${ }^{65}$ This essay would argue that a similar categorical response is likely in New Zealand if the RSP Bill were to succeed.

One problem the author foresees (in addition to driving the sex industry underground, which will be discussed later) is that if street-based prostitution is prohibited in current problem areas, such as central business districts, street-based prostitutes will have no choice but to move deeper into residential areas. This is evidenced by issues in Christchurch where, following the earthquakes and subsequent rendering of the central city as unsuitable for street-based prostitution, street-based prostitutes moved to residential areas like St Albans. ${ }^{66}$ This will only work to exacerbate concerns around neighbourhood nuisance and already heightened tensions between local residents and prostitutes. In the United Kingdom for example, greater streetbased prostitute presence in residential areas incited vigilantism among members of the community who formed community action groups that sought to undertake illegitimate quasipolicing roles to address this issue. ${ }^{67}$ This has proved an issue in Papatoetoe. Concerned residents formed the "Papatoetoe Residents Reclaiming Our Streets" group attempted to undertake street night patrols. ${ }^{68}$ This ultimately resulted in increased violence on the streets, showing how displacement and thus legislation like the RSP Bill or PRAB will frustrate the issues around street-based prostitution. ${ }^{69}$

\footnotetext{
${ }^{62}$ Sanders, above $\mathrm{n}$ 61, at 147.

${ }^{63}$ At 147.

${ }^{64}$ At 147.

${ }^{65}$ At 147.

${ }^{66}$ Jarrod Booker "Quake city wants proposed street prostitute law extended The New Zealand Herald (online ed, New Zealand, 2 March 2012).

67 Sanders, above n 61, at 139.

${ }^{68}$ Phil Taylor "Street legal: Ten years after prostitution decriminalisation" The New Zealand Herald (New Zealand, 8 June 2013).

${ }^{69}$ Phil Taylor "Street legal: Ten years after prostitution decriminalisation" The New Zealand Herald (New Zealand, 8 June 2013).
} 
(b) Exacerbation of violence on the streets

The nature of street-based prostitution naturally gives rise to risks of physical violence, especially when occurring underground. ${ }^{70}$ However, despite studies suggesting that streetbased prostitution is more conducive to violence than indoor prostitution (such as the earlier mentioned Plumridge and Abel study), there is contention among commentators about whether this is in fact accurate. According to Farley, street-based prostitutes have more control over the conditions of their lives than indoor prostitutes. ${ }^{71}$ For example, in practice brothel owners generally refuse prostitutes the right to reject a customer despite legislative prohibition, whereas street-based prostitutes have more liberty to reject customers. ${ }^{72}$

Further, a decriminalised environment allows street-based prostitutes greater ability to screen clients for potential risk. ${ }^{73}$ This is termed "the prostitution trust game," the initial negotiation where the prostitute endeavours to critically judge the prospective client's intent and the likelihood of the encounter becoming violent. ${ }^{74}$ Williamson and Folaron note, "a mismatch between a worker's fundamental appraisal and the customers' true intent may result in a violent encounter." ${ }^{75}$ Hence, this process is best undertaken slowly and cautiously. A decriminalised regime allows this because prostitutes do not fear arrest so negotiations can occur in well-lit, public places where there is appropriate police support.

The scheme proposed by the PRAB will undermine this risk-management strategy by restoring fear of arrest, through the introduction of s 7B to the PRA. Section 7B gives police the power of arrest without warrant over any person suspected, with good cause, of contravening s 7A; essentially any person thought to be engaged in street-based prostitution. ${ }^{76}$ This power extends to authority to stop vehicles if it is reasonably believed a person suspected of engaging in street-

\footnotetext{
70 Jan Jordan The Sex Industry in New Zealand: A Literature Review (Ministry of Justice, March 2005) at 15.

${ }^{71}$ Farley, above n 4, at 1101.

72 At 1101.

${ }^{73}$ As cited in Armstrong, above n 15, at 95.

${ }^{74}$ As cited in Armstrong, above n 15, at 95.

${ }^{75}$ As cited in Armstrong, above n 15, at 95.

${ }^{76}$ Prostitution Reform (Control of Street Prostitution and Their Clients) Amendment Bill, cl 6.
} 
prostitution is in the vehicle. ${ }^{77}$ The scope of this provision mean both parties are liable to arrest from the moment a transaction is initiated on the street, regardless of where they intend to complete the transaction.

Thus, initial negotiations and transport to the rendezvous will be undertaken hurriedly and covertly, if not forgone entirely, heightening the likelihood that the prostitute enters into a transaction with a violent client. ${ }^{78}$ Examples from the United Kingdom and Sydney show that aggressive policing strategies have resulted in reports of street-based prostitutes entering client's vehicles as quickly as possible to avoid detection by authorities. ${ }^{79}$ In New Zealand, this was the case prior to the PRA where initial negotiations between the prostitute and prospective client occurred away from public places. ${ }^{80}$ Prostitutes with experience before and after the PRA have reported significant change, suggesting experiences of negotiations occurring in "real shady" places, and that "a lot of us had to hide before then." ${ }^{81}$ Moreover, it is argued that perceived increase of street-based prostitution is only an increased visibility, as prostitutes move to undertake negotiations with clients in public places more conducive to safety. ${ }^{82}$

Additionally, this fear of arrest will drive prostitution underground. If a prostitute fears arrest based on an officer's good cause to suspect, she will merely engage in the transaction out of police view. This will exacerbate risks of violence as, in Hubbard's words, this inevitably works to create more vulnerable areas. ${ }^{83}$ In the United Kingdom, police crackdowns of the zerotolerance regime created a complex, invisible and underground sex industry. ${ }^{84}$ Transactions were more likely to occur in dangerous environments such as "crack houses." ${ }^{85}$ This shows that a punitive legislative attempt to ameliorate harms of street-based prostitution only worked to aggravate issues of violence.

\footnotetext{
${ }^{77}$ Prostitution Reform (Control of Street Prostitution and Their Clients) Amendment Bill, cl 6.

78 Armstrong, above n 15, at 110-111.

${ }^{79}$ At 111.

${ }^{80}$ At $110-111$.

${ }^{81}$ At 111 .

${ }^{82}$ At 112.

${ }^{83}$ Hubbard, above n 8, at 137.

${ }^{84}$ Sanders, above n 61, at 147.

${ }^{85}$ At 147.
} 
(c) Undermining of current tentative support networks

These negative implications of $\mathrm{s} 7 \mathrm{~B}$ of the PRAB will also undermine police ability to support and protect prostitutes from violence. Their ability to protect by warning of dangerous characters in the area or intervening in negotiations which seem perilous will be circumvented. Under a criminalised regime, recourse to police is feared as it is likely to result in the arrest of the prostitute herself, as discussed.

Following the PRA police have sought to develop trusting relationships with street-based prostitutes to promote recourse to them when issues arise. ${ }^{86}$ The building of this relationship has been slow, yet there is growing appreciation among street-based prostitutes that police may be trusted.$^{87}$ For example, it has been reported that prostitutes felt well-supported by police following recent prostitute murders in Christchurch. ${ }^{88}$

Furthermore, Harcourt, Egger and Donovan note that decriminalisation enables prostitutes to seek redress against exploitation or poor work conditions without exposing themselves to criminal charges or criminal back-pay. ${ }^{89}$ This has proved true in New Zealand; there are many reports of prostitutes seeking police assistance when customers become abusive or refuse to pay. ${ }^{90}$

A criminalised regime also undermines support given by community agencies as it creates fear that a support worker will report the prostitute to police..$^{91}$ This will be discussed later when considering the implementation of social initiatives.

(d) Marginalisation of an already vulnerable class of people

\footnotetext{
${ }^{86}$ Armstrong, above n 15, at 173.

${ }^{87}$ At $169-172$.

${ }^{88}$ At 170 .

${ }^{89}$ Harcourt, Egger and Donovan, above n 15, at 126.

${ }^{90}$ At 172.

${ }^{91}$ Correspondence with Salvation Army support workers in Christchurch.
} 
It may be argued that proponents of a re-criminalised regime merely desire to move prostitution out of sight, out of mind. The RSP Bill and the PRAB seem to be primarily focused on "cleaning up the streets," to put it colloquially, rather than ensuring a safe and well-supported environment. Arguably underpinning this motivation is a hierarchical distinction identified by Hubbard between "higher-class" indoor prostitutes and "lower class" street-based prostitutes. ${ }^{92}$ This has been the case in New Zealand where minority groups, particularly transgender, Maori, and Pasifika prostitutes, experience difficulty obtaining employment in brothels due to inherent discrimination. ${ }^{93}$ Farley argues that it is simply class prejudice to assume that street-based prostitution is worse than "high-class escort" prostitution. ${ }^{94}$

Therefore, this paper argues that legislation as proposed by the RSP Bill and the PRAB will only work to further marginalize a group of already vulnerable people. Section 7A(5) of the PRAB provides that conviction under subsections (1)-(4) (see above) will result in a fine not exceeding \$2,000..$^{95}$ This is a significant penalty and ill-affordable for many engaged in streetbased prostitution, often facing addiction, child support expenses and other basic living costs. ${ }^{96}$ Such a fine would be paid by reversion to further prostitution, as seen in the United Kingdom with the implementation of the Criminal Justice Act 1982 introducing a system of fines for conviction of street-based prostitution offences. Hubbard found that many prostitutes became caught in a vicious circle of arrests and fines as they continued to solicit to pay fines. ${ }^{97}$

Proponents of the PRAB fail to understand these cyclic ramifications, arguing that legislation will cause a shift in societal thinking and cause street-based prostitutes to explore their potential through seeking alternative employment. ${ }^{98}$ This sentiment is naïve. There is consensus among academics that the label of prostitution carries inherent stigma, and re-criminalisation would undermine attempts made thus far to remedy this. ${ }^{99}$ According to Abel and Fitzgerald, the law

\footnotetext{
${ }^{92}$ Hubbard, above n 8, at 129.

${ }^{93}$ Report of the Prostitution Law Review Committee, above n 9, at 120.

${ }^{94}$ Farley, above n 4, at 1101.

95 Prostitution Reform (Control of Street Prostitution and Their Clients) Amendment Bill, cl 6.

${ }^{96}$ Report of the Prostitution Law Review Committee, above n 9, at 119.

${ }^{97}$ Hubbard, above n 8, at 137.

${ }^{98}$ Rebecca Wright "MP aims to end street prostitution” 3 News (online ed, New Zealand, 18 March 2014.)

${ }^{99}$ Farley, above n 4, at 1092.
} 
has had little or no impact on the social perception of prostitutes as deviants of society. ${ }^{100}$ Prostitutes are visible as a social nuisance or "problem", yet invisible as human beings. ${ }^{101}$ Therefore, the proposed penalties and conviction will only further hinder one's ability to gain future "respectable employment," which is the alleged desire behind the PRAB. Obtaining alternative employment was difficult prior to the PRA. Jordan noted that a prostitution-related conviction restricted future employment, travel and access to finance, and re-creating a criminalised regime will arguably only restore these difficulties. ${ }^{102}$

(e) Little effect on the issue of underage prostitution.

The current legal framework has seemingly had little effect on the issue of underage prostitution ${ }^{103}$ Under the PRA, underage prostitutes are considered victims and not criminalised. ${ }^{104}$ This paper does not suggest this is inappropriate. However, this approach seems to promote an attitude among underage prostitutes that because they personally are not committing an illegal or criminal act they are not doing anything wrong. ${ }^{105}$

The RSP Bill and the PRAB will not affect underage persons engagement in street-based prostitution because the legal changes they propose are unlikely to apply to underage prostitutes. Eighteen has been specifically identified as the age at which one can be recognised to voluntarily engage in prostitution and thus be expected to comply with the legal rights and responsibilities set out in prostitution-related law. ${ }^{106}$ This is consistent with the United Nations Convention on the Rights of the Child and the International Labour Organisation Convention 182. ${ }^{107}$ The Prostitution Law Review Committee (PLRC) emphasised the importance of New Zealand's prostitution law maintaining consistency with international law. ${ }^{108}$ So, as there no

\footnotetext{
100 Abel, Fitzgerald, Healy and Taylor, above n 13, at 241.

${ }^{101}$ Farley, above n 4, at 1092.

102 Jordan, above n 70, at 20.

${ }^{103}$ Report of the Prostitution Law Review Committee, above n 9, at 106.

104 At 101-102.

105 Abby Gillies “Underage prostitutes earning \$600 per night” Otago Daily Times (online ed, Dunedin, 27 March 2013).

${ }^{106}$ Report of the Prostitution Law Review Committee above n 9, at 101.

107 At 16.

108 At 16 .
} 
explicit provision in the RSP Bill or the PRAB amending the age of 18, it would seem unlikely that the either Bill, if successful, would be interpreted inconsistently with such clear international obligations.

Moreover, the RSP Bill or the PRAB will not remedy the deeper issues behind a young person's engagement in street-based prostitution. These are issues such as poverty, family violence, alcohol and drug abuse, mental health issues and so forth. ${ }^{109}$ Until these issues are addressed, underage prostitution will remain a significant concern. The desire for accommodation, food, safety, and protection often outweighs potential risks of underage prostitution. ${ }^{110}$ In fact, the consequences may be welcome for some involved in underage prostitution. "Being caught" may result in government or police intervention to force removal from the streets.

\section{B Criminalisation, in general, is inappropriate for these issues}

The following section of this essay will consider arguments around the ill-effects of deterrence to show why criminalisation in any manner is inappropriate for addressing the harms of streetbased prostitution. Experiences of comparative jurisdiction, in particular the Nordic states, support this argument.

The author does not believe that many prostitutes enter the industry of their own volition and agrees that despair, degradation, decline and early death are common characteristics of the sex industry. ${ }^{111}$ There are countless reports of professionals leaving well-regarded employment to engage in prostitution that allegedly support the argument that entry into prostitution can be a rational choice. ${ }^{112}$ This paper would argue, however, that such reports obscure the myriad of factors present behind the "label" of professional or the "talk" of empowerment and choice. ${ }^{113}$ These are circumstances such as addiction, poverty, experiences of abuse, unemployment and homelessness.

\footnotetext{
${ }^{109}$ Save the Children, as cited in New Zealand Prostitutes Collective "Submission to the Local Government and Environment Select Committee on the Manakau City (Regulation of Prostitution in Specified Places) Bill 2010”.

${ }^{110}$ Report of the Prostitution Law Review Committee above n 9, at 103.

${ }^{111}$ Sanger, as cited in Farley, above n 4, at 1097.

112 Extensive analysis of the "choice" arguments are, unfortunately, outside the scope of this paper. For more detailed discussion of the arguments see Armstrong, above n 15, at 12-16, and Farley, above n 4, at 1087-1117.

113 Armstrong, above n 15, at 12-16, and, Farley, above n 4, at 1087-1117.
} 
These broader circumstances behind entry into prostitution mean criminalisation is an inappropriate solution to its harms because often the purpose of legislative prohibition is merely to conceal prostitution rather than address the underlying issues. Hence the legislative proposals targeted solely at street-based prostitution. ${ }^{114}$ This manifests in punitive sanctions for prostitution-related offences, which are focused on aims of deterrence. ${ }^{115}$ This approach is ineffective because, in Robinson and Darley's words, potential offenders rarely know or understand the legal rules in question. Besides, even if these rules are known, often the costbenefit analysis perceived by the potential offender favours violation over compliance with the criminal law. ${ }^{116}$ Knowledge of legislative prohibition and the possibility of resulting sanctions are not enough to guide an individual's conduct when demands from other social, situational or chemical influences are greater. ${ }^{117}$ This is why examples of criminalised regimes show displacement of prostitutes underground rather than an actual reduction of street-based prostitutes.

The ineffectiveness of deterrence is evidenced by the Nordic approach to prostitution which criminalises only the purchase of commercial sexual services as well as pimping and procuring. ${ }^{118}$ The clients of prostitutes are criminalised while the prostitutes themselves are considered victims. ${ }^{119}$ This approach draws on abolitionist feminist discourse which states no woman could ever engage in prostitution of her own free will and that prostitution is violence against women and undermines sexual equality. ${ }^{120}$

The Nordic approach has been commended by Canada and the United Kingdom, currently looking to reform their own prostitution laws. ${ }^{121}$ However, this paper will argue this approach

\footnotetext{
114 Harcourt, Egger and Donovan, above n 15, at 122.

115 At 122.

${ }^{116}$ Robinson and Darley, above n 50, at 174.

117 At 174.

118 May-Len Skilbrei and Charlotta Holmström “Is There a Nordic Prostitution Regime?” 40 (2011) Crime \& Just. 479 at $481-482$.

${ }^{119}$ At 482.

120 At 481-482.

${ }^{121}$ Nigel Morris "MPs call for prostitution to be legalised, but demand tough new penalties on pimps" The Independent (United Kingdom, 3 March 2014); Angela Campbell "For sex workers the Nordic model still falls short” (20 May 2014) The Globe and Mail <www.theglobeandmail.com>.
} 
is ineffective because it creates discriminatory double standards. This was an issue in New Zealand before the PRA. Such a legislative scheme merely reverses the discrimination from the prostitute to the client. This can have serious ramifications such as an increase in violent clients, an increase in unreasonable and unsafe client demands, and failure of clients to report violence they may witness for fear they too will be arrested. ${ }^{122}$

Advocates of the Nordic model argue that issues arising from prostitution can be remedied by reducing demand. ${ }^{123}$ However, there is limited evidence supporting this. In Sweden for example, despite claims that the law caused a change in attitude towards prostitution and reduced street-based prostitution by half, there are strong counter arguments to such success claims, particularly that it is too soon to determine the long term effect of the legislative change. ${ }^{124}$ Critics note that favourable conclusions are based on weak empirical grounds and are unsubstantiated. ${ }^{125} \mathrm{~A}$ decrease in visible street-based prostitutes does not equate to an overall decrease in prostitution, but may suggest prostitution has been driven underground. ${ }^{126}$ Swedish police have found that potential clients simply seek to contact prostitutes out of police view, even going as far as to complete transactions inside taxi-cabs. ${ }^{127}$ Again, this is evidence of a criminal legislative approach exacerbating the harms of street-based prostitution.

Of note, Skilbrei and Holmström argue that there is no conclusive relationship between prostitution laws and the size and composition of the prostitution market, regardless of whether prostitution is criminalised, de-criminalised or only clients criminalised. ${ }^{128}$ However, they do suggest that the prostitution market is affected by the interplay of non-legal measures. ${ }^{129}$ The following section of this essay will argue implementation of social measures is the best means to address issues around street-based prostitution in New Zealand.

\footnotetext{
${ }^{122}$ Angela Campbell "For sex workers the Nordic model still falls short" (20 May 2014) The Globe and Mail <www.theglobeandmail.com>.

${ }^{123}$ Skilbrei and Holmström, above n 118, at 481-482.

${ }^{124}$ At $489-490$.

${ }^{125}$ At $489-490$.

${ }^{126}$ At $489-490$.

${ }^{127}$ At $489-490$.

${ }^{128}$ At 488

${ }^{129}$ At 488
} 


\section{$V$ Alternative Measures for Addressing Issues around Street-based Prostitution}

\section{A Enforcement of the current legal framework}

By arguing against a legislative solution the author does not wish to trivialise the harm streetbased prostitution is having on local communities. However, there are already sufficient legislative provisions and regulations in place that would adequately address harms of nuisance, violence and displays of offensive behaviour. Former Member for Parliament Mark Blumsky argued that many of the issues complained of were not about prostitution itself, but rather issues around noise, litter, graffiti and public nuisance. He stated, "there is a hell of a lot of law out there now that can be used to address these problems..."130

For example, the Litter Act 1975 prohibits disposal of litter in or on public or private land that is likely to endanger another person by causing physical injury, disease or infection. ${ }^{131}$ This provision could be invoked to address issues around the discarding bodily waste, broken glass, liquor bottles, and syringes on business premises and residential property. Additionally, the Resource Management Act 1991 contains provisions against excessive noise and imposes a duty on the local council to respond to noise complaints and issue infringement notices to the perpetrators. ${ }^{132}$ This could be invoked in response to complaints about noise in residential areas caused by the presence of street-based prostitutes. Local councils could also invoke to a greater degree their power to make bylaws regulating alcohol consumption in public places. This would adequately address the broader issues of alcohol-related violence, litter, noise and disorderly behaviour that are claimed to be caused by the presence of street-based prostitutes. Finally, provisions in the Crimes Act 1961, Summary Offences Act 1981 and the Misuse of Drugs Act 1965 are entirely appropriate to address issues of violence and unlawful activities, such as illegal drug use.

Lastly, the PRA provides comprehensive legislation to address this issue of underage prostitution. For example, it is an offence to contract for, or engage in, commercial sex with a

\footnotetext{
130 (11 October 2006) 634 NZPD 5653.

131 The Litter Act 1975, s 15.

${ }^{132}$ Resource Management Act 1991, ss 38 and 327.
} 
person under $18 .{ }^{133}$ It is an offence to cause, assist, facilitate, or encourage, commercial sex with a person under 18, and it is an offence to receive earnings from commercial sex work provided by a person under $18 .{ }^{134}$ This paper would argue these provisions need greater enforcement, as despite a significant presence of underage prostitutes on the streets, there have been few prosecutions under the PRA since enactment. ${ }^{135}$

Addressing the issues around street-based prostitution by enforcing current legislation is a more direct way of addressing the associated harms, as not all issues can be solely attributed to the street-based prostitutes and associated clients. For example, Dr Bennachie of NZPC toured the offending areas and noted an abundance of non-prostitute related litter, including disposable nappies, lunch boxes and bags of household rubbish. ${ }^{136}$

Moreover, legislation of the kind proposed by the CSP Bill, the RSP Bill or the PRAB is an extreme and arguably blind approach to the complex problem of street-based prostitution. Cahn argues that use of the criminal justice system in this manner serves to give control over women's behaviour to the state. ${ }^{137}$ The law is based on community and public norms and does not reflect the needs of outsider groups. ${ }^{138}$ The specific needs of minority social groups are unable to be met with the required sensitivity because of the difficulty such groups have in influencing policy. ${ }^{139}$ This is reflected by the outcry around the harms of street-based prostitution that prompted an extreme legislative solution, showing why the criminal sanction is inappropriate for such issues. More emphasis has been given to the concerns of the majority, the concerned Papatoetoe and central Christchurch residents, than the needs of the prostitutes. A balance must be struck between the needs of both concerned groups. Legislation as broad and as extreme as proposed does not strike this balance. What will achieve this is enforcement

\footnotetext{
${ }^{133}$ Prostitution Reform Act s 22.

${ }^{134}$ Prostitution Reform Act ss20 and 21.

${ }^{135}$ Report of the Prostitution Law Review Committee above n 9, at 106-108.

${ }^{136}$ New Zealand Prostitutes Collective "Submission to the Local Government and Environment Select Committee on the Manakau City (Regulation of Prostitution in Specified Places) Bill 2010”.

${ }^{137}$ Naomi Cahn "Policing Women: Moral Arguments and the Dilemmas of Criminalization" (2012) 49 DEPAUL L. REV. 817 at 821.

${ }^{138}$ At 821.

139 At 821.
} 
of the current law, which is general and applicable to all perpetrators, and the implementation of targeted social initiatives.

\section{B Implementation of targeted social initiatives}

The following section of this essay will outline possible social initiatives that could be implemented in New Zealand to address the discussed harms of street-based prostitution.

(a) Installation of rubbish bins, lighting, public toilets and longer opening hours for needle exchange facilities

First, local councils should work to encourage safer and cleaner environments by installing additional rubbish bins, street lighting and public toilets (especially ones accessible all hours) and encouraging longer opening hours of needle exchange facilities. This was recommended by the PLRC when reviewing the PRA in 2008 and should be further implemented in conjunction with increased support of NZPC. ${ }^{140}$ NZPC currently undertakes responsibility to remove traces of condoms and associated litter and works to liaise with street-based prostitutes to promote more orderly and considerate behaviour. ${ }^{141}$ Councils should work to enhance the relationship between NZPC, the local authority, street-based prostitutes, and the local community. This would help to remedy issues around neighbourhood nuisance.

(b) Increased support given by community agencies

Community support agencies, often working in conjunction with NZPC, also provide an invaluable support network for street-based prostitutes. For example, the Salvation Army operates a street outreach service (SOS) in Christchurch. Volunteers serve food and drink and work to build supportive relationships with street-based prostitutes. ${ }^{142}$ These services should be encouraged and further funded to allow volunteers to better support street-based prostitutes.

\footnotetext{
${ }^{140}$ Report of the Prostitution Law Review Committee above n 9, at 128-129.

${ }^{141}$ At 128.

${ }^{142}$ Living counter culturally, talk sheet on prostitution (Salvation Army, Moral and Social Issues (Ethics) Council New Zealand, Fiji and Tonga Territory, November 2012).
} 
Again, this was recommended by the PLRC. ${ }^{143}$ They suggested community services should be better equipped to provide health and safety advice and information and promote exit from the industry. ${ }^{144}$ The SOS currently does work to assist exit from the industry by the slow, yet deliberate building of relationships via the street-prostitute drop in centre. The former coordinator of this service remarked, "as they returned each week, the talking about changing their lives became active and we began to lose faces from the street scenes." 145

This paper also suggests establishment of drop in centres in recognised prostitution problem areas may reduce the harms of street-based prostitution. Such spaces create environments conducive to the development of meaningful relationships between prostitutes and support workers. These spaces would provide hot drinks, food, clean and appropriate bathrooms, access to health and safety information and other support services. They could also provide temporary short term (one night to one week, for example) accommodation for prostitutes in crisis situations that would work to mitigate issues of violence by providing a safe space for prostitutes to take respite from abusive clients or partners. Implementation of initiatives like these would be more effective than a legislative scheme as proposed by the RSP Bill and the PRAB because they address the underlying issues behind street-based prostitution. The proposed legislative changes only seek to banish prostitution indoors.

This paper recognises Scoular and O'Neil's argument that the neo-liberal agenda, through implementation of support services, promotes social inclusion of those who responsibly exit and "resume normal occupations" and social exclusion of those who remain in street-based prostitution. ${ }^{146}$ However, this allegation can be confined to practices within criminalised jurisdictions. In fact, such argument reinforces the need for support services to be implemented in a decriminalised regime. Decriminalisation works to politically reinforce the notion of prostitution as a legitimate occupation, therefore working to avoid political social exclusion of street-based prostitutes. (As discussed, whether this occurs in practice is another issue). Support within this environment can thus be more than facilitation of exit but also unconditional support

\footnotetext{
${ }^{143}$ Report of the Prostitution Law Review Committee above n 9, at 131. ${ }^{144}$ At 131.

${ }^{145}$ Living counter culturally, talk sheet on prostitution (Salvation Army, Moral and Social Issues (Ethics) Council New Zealand, Fiji and Tonga Territory, November 2012).

146 Jane Scoular and Maggie O’Neil “Regulating Prostitution: Social Inclusion, Responsibilization and the Politics of Prostitution Reform” (2007) 47 BRIT. J. CRIMINAL 764 at 765.
} 
regardless of whether or not the prostitute wishes to exit the sex industry. For example, supporting a prostitute to lay sexual assault charges, or supporting a prostitute during police investigation. This reinforces the need for temporary support measures such as drop in centres. This broader level of support will ensure, as Cahn argues is necessary, that the justice system is tempered with an understanding of the realities of women's lives. ${ }^{147}$

(c) Safe-house brothels

Safe-house brothels (SHBs) are another social measure that could be implemented in New Zealand. Piloted in Sydney, SHBs were designed to provide safe, indoor accommodation for prostitutes to complete transactions in, yet were not formal brothels as prostitutes were not "managed". ${ }^{148}$ The aim was to reduce occurrence of sexual activity in public places, reduce issues around litter and human waste disposal, and reduce the likelihood of violence by providing appropriate security measures. ${ }^{149}$ These establishments were privately run and generally charged around $\$ 13$ per room. ${ }^{150}$ Health and safety information, free condoms and clean syringes were supplied. ${ }^{151}$

A similar scheme was attempted in Christchurch, but failed as it became a "nexus for criminal activity." However, the issue was not the idea itself, but lack of regulation by the local authority. In Sydney all brothels, including SHBs, are subject to council licence and regulation. ${ }^{152}$ New Zealand councils do not face the same requirements, hence their lack of control over the Christchurch attempt. ${ }^{153}$ However, a similar initiative may be effective in New Zealand if overseen by the local council or a reputable agency such as NZPC. Arguably proposals for a new red-light district in Christchurch represent a similar initiative, albeit outdoors. ${ }^{154}$ Critics of the red-light district have suggested provision of public toilets in the zone

\footnotetext{
${ }^{147}$ Cahn, above n 137 , at 829.

${ }^{148}$ Report of the Prostitution Law Review Committee above n 9, at 128.

149 At 128.

${ }^{150}$ At $128-129$.

151 At 128.

152 At 128.

153 At 128.

${ }^{154}$ Joelle Dally “Trial site for sex workers” The Press (online ed, Christchurch, 10 May 2014).
} 
will work to provide shelter for transactions to occur. ${ }^{155}$ Similar suggestions were made in the United Kingdom, where it was proposed that current informal red-light districts in industrial areas should be recognised formally. ${ }^{156}$ Extension of such zones to include SHBs would provide a more sanitary and respectable shelter for street-based prostitutes to engage in transactions.

(d) Transitional Housing

The PLRC recommended child protection measures should be utilized in conjunction with enforcement of the PRA provisions regarding the issue of underage prostitution. One such measure is transitional housing. This was also recommended by the Select Committee that reviewed the CSP Bill. ${ }^{157}$ Transitional housing is generally designed for persons in crisis situations, residents may be escaping abusive situations, or have particular psychological needs. The houses provide a whānau-like environment where clients are supported into more independent living. For example, residents are encouraged to improve basic life-skills, such as cooking, laundry, budgeting, and employment skills. Clients are also connected with appropriate service providers within the community and encouraged to pursue further education or obtain part-time work. ${ }^{158}$

Transitional housing was also recommended by the Ministry of Justice when recommending best practice for assisting exit from prostitution. ${ }^{159}$ There is evidence suggesting exiting prostitution is far from a one-off process. ${ }^{160}$ Many prostitutes attempt to leave five to six times before successfully exiting. ${ }^{161}$ One reason for this is the lack of adequate support for recently exited street-based prostitutes. In particular the Ministry of Justice argues adequate

\footnotetext{
155 Joelle Dally “Trial site for sex workers” The Press (online ed, Christchurch, 10 May 2014).

${ }^{156}$ Hubbard, above n 8, at 138.

${ }^{157}$ Manukau City Council (Control of Street Prostitution) Bill 2005 (6-1) (select committee report) at 5.

158 The author draws on personal experience working in these houses, particularly extensive experience in the Salvation Army run, Sanctuary House and brief experience in the Wellington Women's Boarding House. For more information about these services see The Salvation Army "The Inn and Sanctuary House" (2013) $<$ www.salvationarmy.org.nz> and "Wellington Women's Boarding House" < wwbh.org.nz>.

${ }^{159}$ Pat Mayhew and Dr Elaine Mossman Exiting Prostitution: Models of Best Practice (Ministry of Justice, October 2007) at 32-33.

160 At 7-10.

161 At 7-10.
} 
accommodation is critical to finding routes of prostitution. ${ }^{162}$ For example, women with access to refuge and housing are more likely to exit prostitution than those without. ${ }^{163}$ Transitional housing is one way of providing this and is well-suited to the often unstable nature of prostitutes and also for underage prostitutes. ${ }^{164}$

This paper recommends transitional housing initiatives be extended to specifically target prostitutes exiting the industry. Such initiatives could target certain at-risk groups, for example, Maori and Pasifika youth. Sanctuary House and the Wellington Women's Boarding House could be used as examples of best practice to base further initiatives on. However, such houses require increased funding and support. For example, Awhina Teina in Auckland provided accommodation to young women under age 17 in Auckland who had been identified at risk of prostitution. ${ }^{165}$ Despite steady referrals since 2005, this house was forced to close for lack of funds and volunteers. ${ }^{166}$ This paper would argue resources spent on transitional housing initiatives would be more effective in reducing underage prostitution than legislation. This is because these initiatives work to foster community, build self-identity in the young person, provide appropriate support for dealing with the deeper circumstances at play in the young person's life and ensure a close network of support as the young person transitions from the street into "normal" society.

\section{(e) Education}

This paper would also suggest education initiatives could be implemented to address issues around street-based prostitution, particularly issues around underage prostitution. In the United Kingdom a marketing campaign has been utilised in efforts to deter kerb-crawling. ${ }^{167}$ This campaign used posters and radio adverts to "warn" audiences of potential ramifications of a kerb-crawling conviction. ${ }^{168}$ Presenters relayed real-life stories of ordinary men convicted of

\footnotetext{
162 At 7-10.

${ }^{163}$ Mayhew and Mossman, above n 159, at 32.

164 At 10.

165 At appendix 1.

166 At appendix 1.

${ }^{167}$ Sanders, above n 61, at 150-153.

${ }^{168}$ At $150-153$.
} 
prostitution related offences and emphasis was placed on the effect this had on their families and the shame of conviction. ${ }^{169}$

This is not directly relevant to New Zealand as prostitution is illegal in the United Kingdom. However, perhaps this idea could be manipulated and used as a model to create a similar campaign suitable to New Zealand conditions. Such as, the targeting of potential clients of underage prostitutes. This would affect the issue of underage prostitution by reducing demand and by raising awareness of the issue so as to encourage people to inform authorities when suspicions of underage prostitution are raised. Sanders suggests these campaigns could be internet-based, for example, pop-ups or sidebars on websites relating to prostitution. ${ }^{170}$

These discussed social initiatives, increased street-lighting, rubbish bins, available public toilets, drop in centres, SHBs, transitional housing and education campaigns are only a few examples that could be utilized to address issues of street-based prostitution. Yet, they are imperative because they work to address the deeper circumstances behind engagement in prostitution and thus work to provide meaningful solutions to the issues these women face, whether this involves exit from the industry or support in the industry. In the words of Cahn, legislation alone cannot provide this meaningful solution to the harms of street-based prostitution. ${ }^{171}$

\section{Conclusion}

Street-based prostitution is a current concern in New Zealand. Harms such as neighbourhood nuisance, the presence of violence, increased unlawful or immoral behaviour and underage prostitution are prompting calls for further legislative reform to New Zealand's current decriminalised prostitution regime. This paper has considered three proposed legislative attempts that essentially purport to re-criminalise street-based prostitution in the belief that recriminalisation will address these discussed harms.

\footnotetext{
${ }^{169}$ Sanders, above n 61, at 150-153.

${ }^{170}$ At 159.

${ }^{171}$ Cahn, above n 137, at 828.
} 
This paper has argued however, that these legislative provisions, if enacted, will only work to frustrate the harms of street-based prostitution. They will exacerbate violence on the street, displace prostitutes to alternate areas or drive prostitution underground, and prevent and frustrate exit from street-prostitution because of the stigma the proposed conviction will cause.

This paper has recognised prostitution and the harms around street-based prostitution as significant concerns. Prostitution is exploitative, degrading and demeaning for women. However, criminalisation is not an appropriate means to address this issue. It will not deter women from prostitution because there are always much greater circumstantial pressures behind ones entry into prostitution.

Therefore, this paper has concluded enforcement of current provisions that address the specific behaviour causing these identified harms, coupled with targeted social initiatives will best work to alleviate the harms around street-based prostitution. This is because they are focused on supporting the prostitute within the industry and also in facilitating exit from the industry. In brief, the social measures proposed were: (a) implementation of street lighting, available public toilets, rubbish receptacles and longer opening hours for needle exchange services; (b) increased support given by community agencies and the use of drop in centres; (c) the implementation of SHBs; (d) increased use of targeted transitional housing; and, (e) the use of education to raise awareness and deter potential clients. This paper accordingly suggests that, rather than further legislation to control street-based prostitution in order to reduce associated harms, greater funding and support given to non-legislative approaches will be the most appropriate and effective means of addressing street-based prostitution. 


\section{Word count}

The text of this paper (excluding table of contents, footnotes, and bibliography) comprises approximately 7,761 words.

\section{Bibliography}

\section{Legislation}

Litter Act 1979.

Manukau City Council (Control of Street Prostitution) Bill 2005 (6-1).

Manukau City Council (Regulation of Prostitution in Specified Places) Bill 2010 (197-1).

Prostitution Reform (Control of Street Prostitution and Their Clients) Amendment Bill 2014.

Prostitution Reform Act 2003.

Resource Management Act 1991.

\section{Books and chapters in books}

David Canter, Maria Ioannou and Donna Youngs (eds) Safer Sex in the City: The Experience and Management of Street Prostitution (Ashgate Publishing Limited, Surrey, 2009).

Gillian Abel, Lisa Fitzgerald, Catherine Healy and Aline Taylor (eds) Taking the crime out of sex work: New Zealand sex workers' fight for decriminalisation (The Policy Press, Bristol, 2010).

Teela Sanders, Maggie O'Neil and Jane Pitcher Prostitution; sex work, policy and politics (SAGE Publications Ltd, London, 2009).

Teela Sanders, Paying for pleasure: Men who buy sex (Willan Publishing, Devon, 2008) at ch 7.

Heli Askola Legal Responses to Trafficking in Women for Sexual Exploitation in the European Union (Hart Publishing, Portland, 2007).

\section{Journal articles}

Arthur Gould "The Criminalisation of Buying Sex: The Politics of Prostitution in Sweden" (2001) 30 J SOC POLICY 437.

Ceri Warnock and Nicola Wheen "Sex Work in New Zealand: The Re-Importation of Moral Majoritarianism in Regulating a Decriminalized Industry” 24 (2012) CJWL 414.

Christine Harcourt, Sandra Egger and Basil Donovan "Sex work and the law" (2005) 2 Sexual Health 121. 
Jane Scoular and Maggie O'Neil "Regulating Prostitution: Social Inclusion, Responsibilization and the Politics of Prostitution Reform" (2007) 47 BRIT. J. CRIMINAL 764.

John Lowman and Christine Louie "Public Opinion on Prostitution Law Reform in Canada" 54 (2012) Can. J. Crim. 245.

May-Len Skilbrei and Charlotta Holmström "Is There a Nordic Prostitution Regime?" 40 (2011) Crime \& Just. 479.

Melissa Farley "Bad for the Body, Bad for the Heart: Prostitution Harms Women Even if Legalized or Decriminalized" (2004) 10 Violence Against Women 1087.

Naomi Cahn "Policing Women: Moral Arguments and the Dilemmas of Criminalization" (2012) 49 DEPAUL L. REV. 817.

Paul H Robinson and John M Darley "Does Criminal Law Deter? A Behavioural Science Investigation" (2004) 24 OJLS 173.

Phil Hubbard "Red-light districts and Toleration Zones: geographies of female street prostitution in England and Wales" (1997) 29 Area 129.

Ronald Weitzer "The Social Construction of Sex Trafficking: Ideology an Institutionalization of a Moral Crusade" (2007) 35 Polit Soc 447.

\section{Parliamentary and government materials}

Dr Elaine Mossman International Approaches to Decriminalising or Legalising Prostitution (Ministry of Justice, October 2007).

Jan Jordan The sex industry in New Zealand: A literature review (Ministry of Justice, March 2005).

Manukau City Council (Control of Street Prostitution) Bill 2005 (6-1) (select committee report).

Pat Mayhew and Dr Elaine Mossman Exiting Prostitution: Models of Best Practice (Ministry of Justice, October 2007).

Prostitution Law Reform Committee The Nature and Extent of the Sex Industry in New Zealand: An Estimation (Ministry of Justice, April 2005).

Prostitution Law Reform in New Zealand (Parliamentary Support Research Papers, July 2012).

Report of the Prostitution Law Review Committee on the Operation of the Prostitution Reform Act 2003 (Ministry of Justice, May 2008).

Review of Street-based Prostitution in Manukau City (Ministry of Justice, April 2009).

\section{Hansard}

19 February 2003) 606 NZPD 3607.

(11 April 2006) 634 NZPD 5653. 
(11 October 2006) 634 NZPD 5653.

(8 September 2010) 666 NZPD 13792.

\section{Submissions to Select Committees}

New Zealand Prostitutes Collective "Submission to the Local Government and Environment Select Committee on the Manukau City (Regulation of Prostitution in Specified Places) Bill 2010".

\section{Select Committee Reports}

Manukau City Council (Control of Street Prostitution) Bill 2005 (6-1) (select committee report).

Manukau City Council (Regulation of Prostitution in Specified Places) Bill 2010 (197-1) (interim select committee report).

\section{Dissertations}

Lynzi Armstrong "Managing risks of violence in decriminalised street-based sex work: a feminist (sex worker rights) perspective" (BA $(\mathrm{PhD})$ Thesis Victoria University of Wellington, 2011).

\section{Internet resources}

Auckland City Council "Proposed policy for Auckland's commercial sex industry" <www.aucklandcouncil.govt.nz>.

Auckland City Council "The street prostitution industry in the southern communities of Auckland: the need for legislative control to reflect the intent of the Prostitution Reform Act" (May 2012) <www.aucklandcouncil.govt.nz>

Department of Justice, Canada "Public Consultation of Prostitution-Related Offences in Canada" (17 March 2014) <www.justice.gc.ca>

The Salvation Army “The Inn and Sanctuary House” (2013)<www.salvationarmy.org.nz>.

"Wellington Women's Boarding House" < wwbh.org.nz $>$.

\section{Other resources}

Abby Gillies "Underage prostitutes earning $\$ 600$ per night" Otago Daily Times (online ed, Dunedin, 27 March 2013).

Amy Maas "Obnoxious transvestites descend on corner" Stuff National (online ed, New Zealand, 14 May 2012).

Anna Loren "A waste of time Prostitution law change" Manukau Courier (online Stuff.com ed, Auckland, 30 December 2012).

Ben Guerin “Marion’s Maidens” Salient (Wellington, 30 March 2014). 
Briar Marbeck "Girls intimidated by Chow brothers" 3 News (online ed, New Zealand, 31 January 2014).

Duncan Garner "Girls as young as 12 working as prostitutes in South Auckland" (Podcast, 27 March 2013) Radio Live <www.radiolive.co.nz>.

Hazel Thompson "Prostitution: why Swedes believe they got it right" The Guardian (Stockholm, 11 December 2013).

Living counter culturally, talk sheet on prostitution (Salvation Army, Moral and Social Issues (Ethics) Council New Zealand, Fiji and Tonga Territory, November 2012).

Nigel Morris "MPs call for prostitution to be legalised, but demand tough new penalties on pimps" The Independent (United Kingdom, 3 March 2014).

Phil Taylor "Street legal: Ten years after prostitution decriminalisation" The New Zealand Herald (New Zealand, 8 June 2013).

Rebecca Wright "MP aims to end street prostitution" 3 News (online ed, New Zealand, 18 March 2014).

Sarah Harvey "Prostitute problem desperate" Manukau Courier (online Stuff.com ed, Auckland, 29 July 2011).

Sarah Stuart "Twelve questions with Jacqui Le Prou" New Zealand Herald (online ed, New Zealand, 29 January 2014).

Susana Mas "Prostitution Bill would make it illegal to buy, sell sex in public" CBC News (online ed, Canada, 4 June 2014). 